\title{
ANALISIS PENGARUH CORPORATE SOCIAL RESPONSIBILITY, PROFITABILITAS, DAN SOLVABILITAS TERHADAP NILAI PERUSAHAAN
}

(Studi Empiris Perusahaan Properti, Perumahan, dan Konstruksi Bangunan Yang Terdaftar Di Bursa Efek Indonesia Tahun 2012-2018)

\section{Nova Kristanti*}

*Mahasiswa Program Studi Akuntansi Sekolah Tinggi Ilmu Ekonomi Al Anwar Mojokerto

Sekolah Tinggi Ilmu Ekonomi Al Anwar Mojokerto

Jl. Raya Brangkal Nomor 70 Sooko Mojokerto Kode Pos 61482 Telepon ( 0321) 327-507, 382-693 Fax (0321) 382-693 E-mail: info@ @tie-alanwar.ac.id

Email: novakristanti96@gmail.com

\begin{abstract}
Company Value is a company with certain circumstances as a picture of public or investor confidence in the company during a certain period that shows the shareholders' thinking of the share price that is able to reflect the level of success of an entity. The purpose of this research is to recognize: partially and simultaneously to recognize the influence of CSR, profitability (ROE), and solvency (DER) on the value of the company in the Property and Housing Companies listed on the Indonesia Stock Exchange for the period 2012-2018. The sample of this research is the company Property and Housing listed on the Indonesia Stock Exchange for the period 2012-2018. The way to choose the sample of this study is purposive sampling, especially judgment sampling. The sample consists of 11 entities with a period of 7 years so that a total of 77 entities. Multiple linear regression analysis is a way of analyzing information applied in this research. The results of this research are partially and simultaneously: CSR, profitability (ROE), and solvency (DER) have a significant and positive effect on the value of the company in property and housing companies listed on the Indonesia Stock Exchange in 2012-2018.
\end{abstract}

Keyword: Corporate Social Responsibility (CSR), Profitability (ROE), Solvability (DER), and Company Value (Tobin's Q)

\section{PENDAHULUAN}

Persaingan usaha di Indonesia dikala ini sudah menghadapi persaingan yang sangat ketat. Terlebih dengan mulai berlakunya Warga Ekonomi ASEAN (MEA) Semenjak tahun 2015. Salah satu hal penting yang dijadikan pertimbangan calon penanam saham sebelum menanamkan sahamnya yaitu melihat besar profit perusahaan. Sebab laba yang dihasilkan bisa memprediksi kelangsungan hidup perusahaan dalam jangka panjang (Hery, 2017: 7). MEA pula berakibat spesial pada dunia Properti. Bila memandang secara khusus pasar Properti lokal hendak terjalin pergantian yang kecil di Indonesia. Sebaliknya Pengembang lokal untuk tumbuh memiliki ekuitas yang kokoh serta tidak wajib tergantung kepada pendanaan asing. Mayoritas para pengembang hendak menaikkan pendanaan ekuitas lokal di Indonesia ataupun berutang dalam mata uang asing di sesuatu negera.

Kehadiran produk properti dari para pengambang asing dengan kualitas dan merek yang berstandar internasional, sewajarnya diantisipasi oleh pengembang lokal. Karena bagaimanapun masyarakat akan lebih memilih yang berkualitas tinggi. Hal tersebut membut MEA harus lebih disikapi dan dijadikan sebagai tantangan pengembang lokal untu menghasilkan produk properti yang lebih berkualitas agar siap bersaing dengan asing dengan memanfaatkan teknologi dan keahlian di 
Indonesia yang canggih (Dyah, 2019, https://artikel.rumah123.com).

Selain itu terdapat beberapa berita nyata mengenai properti yang pertama tanggal pada tanggal 30 Agustus 2019 salah satu Perusahaan Properti dan Real Estate yaitu PT Lippo Karawaci (LPKR) mengalami penurunan profitabilitas. Hal ini disebabkan oleh EBITDA dan pendapatan yang menurun. Secara tidak langsung hal ini akan menjadi masukan dan pertimbangan bagi Perusahaan Properti dan Real Estate lainnya. Sehingga perlu diteliti faktor ini dan faktor lain yang bisa mempengaruhi Nilai Perusahaan (Indonesia, 2019, https://www.youtube.com/watch?v=VhBH -WzTFfA). Sedangkan pada tanggal Tanggal 16 Agustus 2019 total penjualan sebagian perusahaan properti mengalami penurunan. Diakibatkan tidak terdapatnya peluncuran produk baru pada Pilpres April 2019, hasil pelacakan Fitch menemukan sedang meghadapi penyusutan sebesar $20 \%$ YoY pada semester I-2019 jadi 15,8 triliun dari total penjualan yang dilaksanakan secara konsolidasi bagi 13 pengembang. Lahan yang diakuisisi hadapi penyusutan pula senilai $60 \%$ YoY. Dampaknya pada akhir kuartal II-2019, normalitas leverage ditingkat $32 \%$. Sebabnya arus kas pembedahan telah menjadi fokus pembetulan semua entitas.

Secara umum ada empat kriteria jika perusahaan memiliki kondisi keuangan yang sehat, yaitu: bertumbuhnya pendapatan (1), rasio profitabilitas masih sehat (2), jumlah pengeluaran yang seimbang (3), tidak banyak berutang (4) (Sleekr, 2017, https://sleekr.co/blog/4-tanda-kondisi-

keuangan-baik/).

Selain empat kriteria tersebut pastinya ada sebagian aspek yang bisa berpengaruh terhadap kekayaan direktur perusahaan serta para pemegang saham dalam mengoptimalkan harga saham. Halhal yang hendak diteliti dalam riset ini merupakan CSR, profitabilitas, serta solvabilitas.
Menurut Permanasari (2010) dalam (Syamsuddin \& Wardani, 2018), CSR adalah aktivitas dengan menitikberatkan dari keseimbangan pada aspek ekonomi, sosial, dan lingkungan hidup publik terutama sekitar perusahaan, stakeholders dan shareholders untuk mempertahankan kepercayaan entitas atau lingkungan bisnis dalam berperan di pembangunan dan pengembangan ekonomi. CSR mempengaruhi secara positif dan signifikan. Menurut beberapa peneliti terdahulu yang sinkron dengan penelitian ini.

$\begin{array}{ccc} & \text { Di Indonesia } & \text { CSR yaitu tanggung } \\ \text { jawab } & \text { sosial } & \text { usaha }\end{array}$ menyelenggarakan kesejahteraan sosial (diatur dalam Permensos 06 periode 2016) pada tanggal 22 April 2016 dengan divalidkan oleh tanda tangan dari Menteri Sosial (Khofifah Indar Parawansa). CSR suatu usaha merupakan sesuatu komitmen serta upaya tubuh usaha ataupun perusahaan buat berfungsi dalam penyelenggaraan kesejahteraan social baik dalam aspek sosial, ekonomi, ataupun area.

Selain itu di Indonesia Pernyataan Standar Akuntansi Keuangan (PSAK) Nomor. 1 (perbaikan 2018) pada dasarnya mengatur pelaporan non keuangan ataupun pelaporan aktivitas berkepanjangan secara universal sebagai berikut: kalau sesuatu entitas bisa menyediakan laporan berbeda dari laporan keuangan, ialah laporan nilai tambah (value added statement) dan laporan sustanibility (lingkungan hidup), spesialnya untuk industri pada lingkungan SAK (I. A. Indonesia, 2018).

Profitabilitas bermakna usaha dalam menjaga kegiatan operasional perusahaan dalam menjalankan usahanya pada masa yang panjang, sebab entitas mampu menunjukkan kesanggupan yang baik untuk prospek di masa depan melalui profitabilitas (Hery, 2017: 7). Rasio Solvabilitas atau leverage ratio ialah rasio pengukur aktiva perusahaan yang menggunakan kewajiban untuk membiayainya (Kasmir, 2016) dalam (Hery, 2017: 12). Maksudnya, perusahaan 
menanggung kewajibannya yang lebih dari satu tahun atau kurang dari satu tahun itu seberapa besar untuk dibayar sebagai beban utang perusahaan (Hery, 2017: 12). Bagi Joel Gram. Siegel serta Jae K. Shim dalam (Fahmi, 2017: 128) Debt Equity Ratio ialah ruang untuk mengetahui besarnya agunan kepada pemberi pinjaman melalui analisis financial report perusahaan. Maksudnya dalam sudut pandang investor, entitas memiliki kepercayaan yang bagus. Dampaknya dipercaya kreditur pada saat membutuhkan tambahan yang berasal dari eksternal, karena mempunyai kemampuan tinggi untuk bayar utang jangka panjang serta menguntungkan. Jadi, nilai perusahaan naik yang diakibatkan dari naiknya harga saham (Lumentut, F. G., \& Mangantar, 2019: 2608).

Pada implementasinya, Risiko kerugian akan besar jika entitas mempunyai solvabilitas yang besar. Namun terdapat pula peluang menemukan profit lebih tinggi. Kebalikannya saat keadaan ekonomi melemah, jika rasio solvabilitas turun juga maka akan menurunkan kerugian. Tingkat pendapatan yang rendah merupakan akibatnya saat perekonomian tinggi.

Dengan alasan-alasan tersebut, sehingga penulis melaksanakan riset dengan judul "Analisis Pengaruh Corporate Social Responsibility, Profitabilitas, dan Solvabilitas Terhadap Nilai (Studi Empiris Pada Perusahaan Properti, Perumahan, dan Konstruksi Bangunan Yang Terdaftar Di Bursa Efek Indonesia Tahun 2012-2018”).

\section{KAJIAN LITERATUR DAN PENGEMBANGAN HIPOTESIS}

Teori Stakeholder

Stakeholder merupakan suatu individu, masyarakat, kelompok, industri, komunitas yang mempunyai kepentingan meupun kekuasaan dengan suatu perusahaan. Old corporate relation dan new corporate relation adalah dua metode dalam teori stakeholder.
Old corporate relation merupakan suatu metode dimana perusahaan melakukan aktifitas secara terpisah dari para pemangku kepentingan, artinya perusahaan hanya mengutamakan kepentingan diri sendiri untuk mendapatkan laba tanpa memperhatikan faktor lain. Sedangkan new corporate relation merupakan suatu hubungan perusahaan dengan menekankan berupaka kerjasama dan memerlukan kontribusi terhadap seluruh stakeholdernya untuk memikirkan kepentingan bersama dalam mecapai laba untuk kesejahteraan perusahaan maupun para stakeholdernya.

\section{Corporate Social Responsibility}

Menurut Permanasari (2010) dalam (Syamsuddin \& Wardani, 2018), CSR adalah aktivitas dengan menitikberatkan dari keseimbangan pada aspek ekonomi, sosial, dan lingkungan hidup publik terutama sekitar perusahaan, stakeholders dan shareholders untuk mempertahankan kepercayaan entitas atau lingkungan bisnis dalam berperan di pembangunan dan pengembangan ekonomi.

Namun rumusan yang diberikan oleh Lee dan Kotler (2005) dalam (Solihin, 2015: 5):

" $a$ belief in promoting public tranquility through the implementation of precarious business and the role of entity resources is the notion of CSR".

\section{Profitabilitas}

"Profitabilitas ialah sesuatu keahlian perusahaan untuk mendapatkan keuntungan dalam periode tertentu ( Ernawati serta Widyawati, 2015 dalam (Hery, 2017: 7). Beberapa indikator sebagai ukuran profitabilitas, seperti: tingkat pengembalian ekuitas pemilik, tingkat pengembalian investasi atau aset, laba bersih dan operasi. Setiap entitas akan mengoptimalkan profitabilitasnya, sebab dengan tingginya rasio tersebut, sehingga kontinuitas hidup perusahaan akan terjaga.

Salah satu rumus dalam menghitung profitabilitas yaitu ROE yang 
diterapkan riset ini. Semakin tinggi ROE mampu meningkatkan nilai perusahaan dengan mengukur kemampuan menghasilkan laba terhadap ekuitas yang dimiliki perusahaan. Karena ekuitas merupakan hal awal yang perlu diperhatikan dalam mengelola suatu usaha yang merupakan tonggak dalam pengeluaran biaya dan kegiatan operasional perusahaan. Dimana jika laba naik maka ekuitas akan naik.

\section{Solvabilitas}

Rasio Solvabilitas ataupun leverage ratio ialah rasio pengukur aktiva perusahaan yang menggunakan kewajiban untuk membiayainya (Kasmir, 2016) dalam (Hery, 2017: 12). Maksudnya, perusahaan menanggung kewajibannya yang lebih dari satu tahun atau kurang dari satu tahun itu seberapa besar untuk dibayar sebagai beban utang perusahaan (Hery, 2017: 12).

Dalam penelitian ini solvabilitas diproksikan dengan DER. Semakin tinggi DER mampu meningkatkan nilai perusahaan dengan mengukur kemampuan membayar kewajiban entitas yang jangka panjang ataupun jangka pendek terhdap modal yang perusahaan miliki. Karena ekuitas merupakan hal awal yang perlu diperhatikan dalam mengelola suatu usaha yang merupakan tonggak dalam pengeluaran bahwa ekuitas tersebut berasal dari utang atau milik sendiri.

\section{Kerangka Pemikiran}

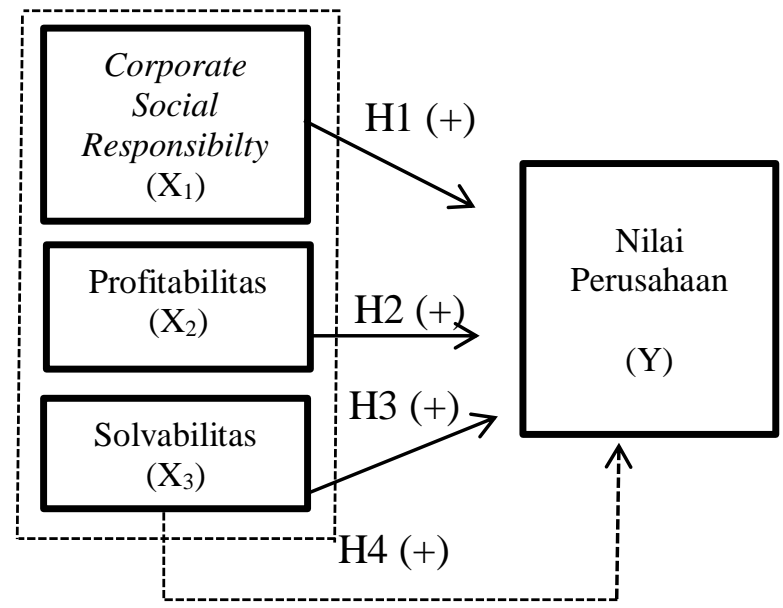

Keterangan:

$\longrightarrow=$ Variabel yang diuji secara parsial

---------> = Variabel yang diuji secara simultan

\section{Hipotesis}

H1: CSR secara parsial diduga berpengaruh positif dan signifikan pada nilai perusahaan di perusahaan properti dan perumahan yang listed di BEI tahun 2012-2018.

$\mathrm{H} 2$ : Profitabilitas secara parsial diduga berpengaruh positif dan signifikan pada nilai perusahaan perusahaan properti dan perumahan yang listed di BEI tahun 2012-2018.

H3: Solvabilitas secara parsial diduga berpengaruh positif dan signifikan pada nilai perusahaan perusahaan properti dan perumahan yang listed di BEI tahun 2012-2018..

H4: CSR, Profitabilitas, dan Solvabilitas secara simultan diduga berpengaruh positif dan signifikan pada nilai perusahaan perusahaan properti dan perumahan yang listed di BEI tahun 2012-2018.

\section{METODE PENELITIAN \\ Data dan Sumber Data}

Data sekunder (data yang sudah ada) ialah data yang dipakai dalam penelitian ini. Data diambil dari (Idx, 2019, www.idx.co.id).

\section{Metode Pengambilan Sampel}

Sebagian Perusahaan Properti dan Perumahan yang listed di BEI periode 2012-2018 ialah sampel riset. Sampel berjumlah 11 perusahaan dengan kurun waktu 7 tahun sehingga total 77 yang diperoleh menggunakan prosedur pengambilan sampel purposive sampling dengan jenis judgment sampling. Kriteriakriteria tersebut yaitu:

1) Perusahaan Properti dan Perumahan listed di BEI tahun 2012-2018.

2) Adanya annual report di web masingmasing Perusahaan Properti dan 
Perumahan selama tujuh tahun (20122018).

3) Perusahaan Properti dan Perumahan yang terdapat catatan CSR di laporan tahunan pada web perusahaan selama tujuh tahun berturut-turut selama periode 2012-2018.

4) Adanya informasi dalam laporan tahunan tahun 2012-2018 mengenai ROE dan DER sebagai rasio keuangan.

5) Adanya informasi yang dibutuhkan untuk menghitung tentang nilai perusahaan melalui Tobins'Q.

6) Perusahaan Properti dan Perumahan yang memiliki data lengkap sebagai kebutuhan dalam penelitian ini, ada yang mengalami kerugian dan ada yang untung dengan kategori jumlah ROE dari tahun 2012-2018 yang paling kecil (diambil jumlah ROE yang tidak mengalami kerugian dari kategori $45,77 \%$; 51,00\%; 65,74\%; dan 109,68\% yang mewakili range angka 40-60 dan 100 dengan kategori paling rendah karena dilihat dari ROE yang jumlahnya paling rendah), serta data CSR, ROE, DER, Tobin's Q Perusahaan Properti dan Perumahan yang memenuhi kriteria hasil dan uji yang diperlukan dalam aplikasi SPSS versi 16.

\section{Definisi Operasional Variabel Penelitian Variabel Independen: \\ Corporate Social Responsibility}

Penghitungan CSR $\left(\mathrm{X}_{1}\right)$ dilakukan dengan menggunakan rumus CSRI dalam bentuk variabel dummy (Syamsuddin \& Wardani, 2018: 6) yaitu :

Keterangan:

$$
\mathrm{CSRIj}=\frac{\sum \mathrm{Xij}_{\mathrm{ij}}}{\mathrm{Nj}}
$$

\section{CSRI :Index pengungkapan CSR}

Perusahaan

$\mathrm{Nj}$ :Total aspek yang digunakan perusahaan, $\mathrm{nj} \leq 78$

Xij : variabel dummy: $1=$ disclosed, 0 =not disclosed maka harus diperoleh CSRIj lebih dari sama dengan 0 atau kurang dari sama dengan 1 .
Dasar pengambilan indikator CSR adalah GRI Standards yang berjumlah 73 dengan 3 aspek (sosial, ekonomi, dan lingkungan).

\section{Profitabilitas}

Profitabilitas $\left(\mathrm{X}_{2}\right)$ diwakili oleh:

$$
\text { ROE = Laba Bersih Setelah }
$$$$
\text { Pajak : Total Ekuitas }
$$

\section{Solvabilitas}

Solvabilitas $\left(\mathrm{X}_{3}\right)$ diwakili oleh:

$$
\text { DER }=\frac{\text { Total Liabilitas }}{\text { Total Ekuitas }}
$$

\section{Variabel Dependen}

Nilai perusahaan diwakili oleh Tobins Q sebagai variabel terikat:

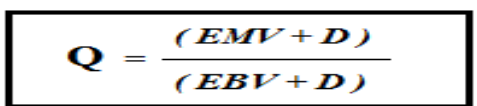

\section{Keterangan:}

Q = nilai perusahaan

Equity Market Value = nilai pasar ekuitas

Equity Book Value = nilai buku dari total aktiva

D

$$
\text { = nilai buku dari }
$$
total utang

EMV diperoleh dari ((closing price) X Outstanding shares)) sedangkan EBV diperoleh dari (total aktiva - total utang).

\section{Metode Analisis Data}

Bentuk persamaan analisis regresi linier berganda:

$$
\mathrm{Y}=\mathrm{a}+\beta_{1} \mathrm{X}_{1}+\beta_{2} \mathrm{X}_{2}+\beta_{3} \mathrm{X}_{3}+\mathrm{e}
$$

$\begin{array}{ll}\text { Keterangan : } & \\ \mathrm{Y} & =\text { Nilai perusahaan } \\ \mathrm{a} & =\text { Konstanta } \\ \mathrm{X}_{1} & \text { Corporate Social } \\ & \text { responsibility } \\ \mathrm{X}_{2} & =\text { Profitabilita } \\ \mathrm{X}_{3} & =\text { Solvabilitas } \\ \beta_{1}, \beta_{2}, \beta_{3} & =\text { Koefisien regresi } \\ \mathrm{e} & =\end{array}$




\section{HASIL PENELITIAN}

Analisis Data

Hasil Analisis Statistik Deskriptif

Tabel 1

Hasil Statistik Deskriptif

\begin{tabular}{|c|c|c|c|c|c|c|}
\hline & $\mathbf{N}$ & $\begin{array}{c}\text { Rang } \\
\text { e }\end{array}$ & \begin{tabular}{|c|} 
Min \\
imu \\
m
\end{tabular} & $\begin{array}{c}\text { Maxim } \\
\text { um }\end{array}$ & Mean & $\begin{array}{c}\text { Std. } \\
\text { Deviati } \\
\text { on }\end{array}$ \\
\hline & \multicolumn{6}{|c|}{ Statistic } \\
\hline $\begin{array}{l}\text { Nilai } \\
\text { Perusahaan } \\
\text { (Tobin's Q) }\end{array}$ & 77 & 2.14 & .12 & 2.26 & .9468 & .44579 \\
\hline CSR & 77 & .04 & .10 & .14 & .1196 & .01434 \\
\hline $\begin{array}{l}\text { Profitabilit } \\
\text { as (ROE) }\end{array}$ & 77 & 50.75 & $\begin{array}{r}24.4 \\
5\end{array}$ & 26.30 & 5.4777 & $\begin{array}{r}8.7219 \\
8\end{array}$ \\
\hline $\begin{array}{l}\text { Solvabilita } \\
\text { s (DER) }\end{array}$ & 77 & $\begin{array}{r}303.0 \\
0\end{array}$ & 4.00 & 307.00 & $\begin{array}{r}59.732 \\
2\end{array}$ & $\begin{array}{r}51.436 \\
04\end{array}$ \\
\hline $\begin{array}{l}\text { Valid N } \\
\text { (listwise) }\end{array}$ & 77 & & & & & \\
\hline
\end{tabular}

Sumber: Data penelitian diolah (2020) oleh SPSS v.16

Simpangan baku nilai perusahaan menunjukkan 0,44579. Mean nya menunjukkan 0,9468. Nilai tertinggi menunjukkan 2,26 yang dimiliki oleh PT Metropolitan Land Tbk periode 2016. Dan Nilai terendah menunjukkan 0,12 yang dimiliki oleh PT Indonesia Prima Property Tbk pada periode 2016.

Simpangan baku CSR menunjukkan 0,01434. Mean nya menunjukkan 0,1196. Rentang nilai CSR dengan proksi CSRI menunjukkan 0,10 hingga 0,14. PT. Perdana Gapura Prima Tbk pada tahun 2012, 2012, 2013, 2014, 2015,2016, 2017, 2018 dan PT. Bhuwanatala Indah Permai Tbk pada tahun 2012, 2014, 2015, 2016, 2017, 2018 adalah pemilik nilai terendah sedangkan PT. Ciputra Development Tbk pada tahun 2012, 2013, 2014, 2015, 2016, 2017, 2018; PT. Lippo Karawaci Tbk pada tahun 2012, 2013, 2014, 2015, 2016, 2017, 2018 dan PT. Cowell Development Tbk pada tahun 2012, 2013, 2014, 2015, 2016, 2017, 2018 adalah pemilik nilai tertinggi.

Simpangan baku profitabilitas menunjukkan 8,72198. Mean nya menunjukkan 5,4777. Rentang nilai
Profitabilitas menunjukkan $-24,45$ hingga 26,30. PT. Cowell Development Tbk pada tahun 2018 ialah pemilik nilai terendah sedangkan PT. Bumi Serpong Damai Tbk tahun 2013 ialah pemilik nilai tertinggi.

Simpangan baku solvabilitas menunjukkan 51,43604. Mean nya menunjukkan 59,7322. Rentan nilai solvabiltas menunjukkan 4,00 hingga 307,00. PT. Indonesia Prima Property Tbk periode 2016 ialah pemilik nilai terendah sedangkan PT. Cowell Development Tbk tahun 2018 ialah pemilik nilai tertinggi.

\section{Hasil Uji Asumsi Klasik Hasil Uji Normalitas}

Gambar 1

Histogram Hasil Uji Normalitas

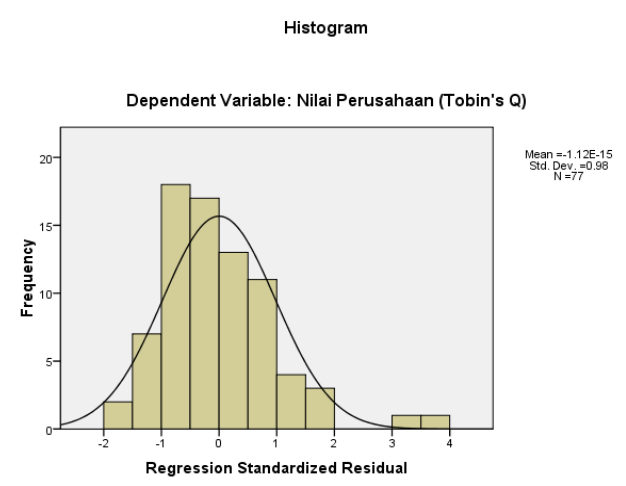

Sumber: Data penelitian diolah (2020) oleh SPSS v.16

Gambar 2

Grafik Normal Probability Plot Hasil Uji

Normalitas

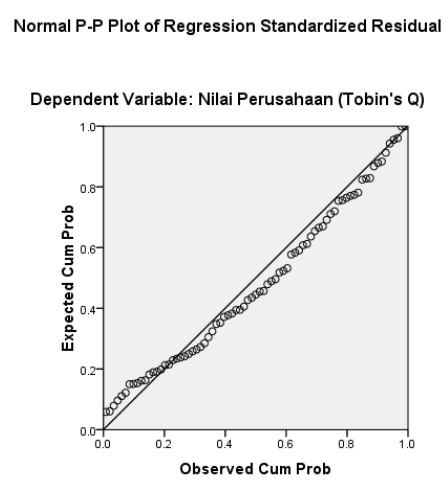

Sumber: Data penelitian diolah (2020) oleh SPSS v.16 
Tabel 2

Hasil Uji Normalitas Melalui One-Sampel Kolmogorov-Smirnov Test

One-Sample Kolmogorov-Smirnov Test

\begin{tabular}{|l|l|r|}
\hline \multicolumn{2}{|l|}{} & $\begin{array}{c}\text { Unstandardized } \\
\text { Residual }\end{array}$ \\
\hline $\mathrm{N}$ & Mean & 77 \\
\hline $\begin{array}{l}\text { Normal } \\
\text { Parameters }\end{array}$ & Std. Deviation & .32581423 \\
\hline $\begin{array}{l}\text { Most } \\
\text { Extreme } \\
\text { Differences }\end{array}$ & Absolute & .078 \\
\cline { 2 - 3 } & Positive & .078 \\
\cline { 2 - 3 } & Negative & -.067 \\
\hline Kolmogorov-Smirnov Z & .684 \\
\hline Asymp. Sig. (2-tailed) & .738 \\
\hline
\end{tabular}

a. Test distribution is Normal.

Sumber: Data penelitian diolah (2020) oleh SPSS v.16

Menurut hasil SPSS versi 16.0 di atas, analisis grafik menunjukkan bahwa grafik histogram yang mengikuti dan membentuk diagonal diantara data frequency dengan regression standardized residual. Sedangkan menurut grafik normalitas bahwa data penelitian ini menunjukkan normal dengan lurus mengikuti satu garis lurus diantara garis expected cum prob dan observed cum prob. Kesimpulannya dari hasil histogram dan grafik normal probability plot data dalam penelitian ini menyebar secara normal. Selain berdasarkan histogram dan normalitas juga dilihat dari nilai signifikansinya harus lebih dari 0,05 . Hasil signifikansi penelitian ini sebesar 0,738. Hal ini jika dilihat dari analisis statistik melalui uji Kolmogorov-Smirnov test. Maka disimpulkan $\mathrm{H}_{0}$ diterima sehingga data residual menyebar secara normal.

\section{Hasil Uji Multikolinieritas}

Tabel 3

Hasil Uji Multikolinieritas Coefficients $^{\text {a }}$

\begin{tabular}{|c|c|c|c|c|c|}
\hline \multirow{2}{*}{\multicolumn{2}{|c|}{ Model }} & \multirow[b]{2}{*}{$\mathbf{T}$} & \multirow[b]{2}{*}{ Sig. } & \multicolumn{2}{|c|}{$\begin{array}{c}\text { Collinearity } \\
\text { Statistics }\end{array}$} \\
\hline & & & & Tolerance & VIF \\
\hline 1 & (Constant) & -.662 & .510 & & \\
\hline
\end{tabular}

\begin{tabular}{|l|l|l|r|r|}
\hline CSR & 2.122 & .037 & .870 & 1.150 \\
\hline $\begin{array}{l}\text { Profitabilitas } \\
\text { (ROE) }\end{array}$ & 4.460 & .000 & .780 & 1.281 \\
\hline $\begin{array}{l}\text { Solvabilitas } \\
\text { (DER) }\end{array}$ & 6.135 & .000 & .732 & 1.366 \\
\hline
\end{tabular}

a. Dependent Variable: Nilai Perusahaan (Tobin's Q)

Sumber: Data penelitian diolah (2020) oleh SPSS v.16

Berdasarkan hasil SPSS v.16.0, menujukkan jika nilai tolerance untuk semua variabel bebas sebesar $>10 \%$ atau 0,1 . Sedangkan nilai variance inflation factor yang diperoleh juga menunjukkan lebih dari 10. Sehingga di persamaan regresi ini tidak terdapat multikolinieritas antar variabl independen Corporate Social Responsibility, Profitabilitas, dan Solvabilitas.

\section{Hasil Uji Heteroskedastisitas}

Gambar 3

Hasil Uji Heteroskedastisitas

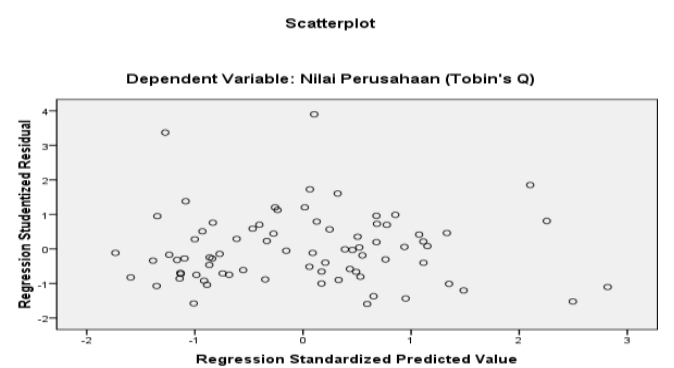

Sumber: Data penelitian diolah (2020) oleh SPSS v.16

Dalam persamaan regresi ini menunjukkan semua titik pada grafik scatterplot, secara random menyebar. Sehingga tidak ada heteroskedastisitas.

\section{Hasil Uji Autokorelasi}

Tabel 4

Hasil Uji Autokorelasi

\begin{tabular}{|c|c|c|c|c|c|}
\hline \multicolumn{6}{|c|}{ Model Summary ${ }^{b}$} \\
\hline Model & $\mathbf{R}$ & $\begin{array}{c}\mathbf{R} \\
\text { Square }\end{array}$ & $\begin{array}{c}\text { Adjusted } \\
\text { R } \\
\text { Square }\end{array}$ & $\begin{array}{c}\text { Std. } \\
\text { Error } \\
\text { of the } \\
\text { Estima } \\
\text { te }\end{array}$ & $\begin{array}{c}\text { Durbin } \\
- \\
\text { Watso } \\
\mathbf{n}\end{array}$ \\
\hline 1 & $.683^{\mathrm{a}}$ & .466 & .444 & .33244 & 1.946 \\
\hline
\end{tabular}


a.Predictors: (Constant), Solvabilitas (DER), CSR, Profitabilitas (ROE)

b.Dependent Variable: Nilai Perusahaan (Tobin's Q) Sumber: Data penelitian diolah (2020) oleh SPSS v.16

Berdasarkan hasil di atas dengan total sampel (t) 77 dan total variabel bebas da terikat 4) serta Durbin-Watson (d) 1,946. Jadi diperoleh Durbin-Lower sebesar 1,5228 dan Durbin-Upper sebesar 1,7407. Maka dapat dihitung dengan kriteria $\mathrm{du}<\mathrm{d}<4$-du sama dengan $1,7407<1,946<2,2593$ (4-du = 4-1,7407). Sehingga hasil uji autokorelasi memenuhi kriteria hipotesis nol menunjukkan durbin upper<durbin watson<4-durbin upper yaitu $1,7407<1,946<2,2593$. Maka disimpulkan tidak terdapat autokorelasi.

\section{Hasil Analisis Regresi Linier Berganda} Tabel 5

Hasil Analisis Regresi Linier Berganda

\begin{tabular}{|c|c|c|c|c|c|}
\hline \multicolumn{6}{|c|}{ Coefficients ${ }^{a}$} \\
\hline \multirow[b]{2}{*}{ Model } & \multicolumn{2}{|c|}{$\begin{array}{l}\text { Unstandardize } \\
\text { d Coefficients }\end{array}$} & \multirow{2}{*}{\begin{tabular}{|c|}
$\begin{array}{c}\text { Standa } \\
\text { rdized } \\
\text { Coeffic } \\
\text { ients }\end{array}$ \\
Beta \\
\end{tabular}} & \multirow[b]{2}{*}{$\mathbf{T}$} & \multirow[b]{2}{*}{ Sig. } \\
\hline & $\mathrm{B}$ & Std. Error & & & \\
\hline \begin{tabular}{|l|l|}
1 & (Constant) \\
\end{tabular} & -.215 & .325 & & -.662 & .510 \\
\hline CSR & 6.050 & 2.851 & .195 & 2.122 & .037 \\
\hline $\begin{array}{l}\text { Profitabilit } \\
\text { as (ROE) }\end{array}$ & .022 & .005 & .432 & 4.460 & .000 \\
\hline \begin{tabular}{|l} 
Solvabilita \\
s (DER)
\end{tabular} & .005 & .001 & .613 & 6.135 & .000 \\
\hline
\end{tabular}

a. Dependent Variable:Nilai Perusahaan (Tobin's Q)

Sumber: Data penelitian diolah (2020) oleh SPSS v.16

Tabel 6

Hasil Eror Dalam Analisis Regresi Linier Berganda

\begin{tabular}{|l|l|}
\hline Model & Std. Eror of the Estimate \\
\hline 1 & .33244 \\
\hline a. Predictors: (Constant), Solvabilitas (DER), \\
CSR, Profitabilitas (ROE) \\
b. Dependent Variable: Nilai Perusahaan \\
(Tobin's Q)
\end{tabular}

Sumber: Data penelitian diolah (2020) oleh SPSS v.16

Berikut hasilnya dari percobaan analisis regresi linier berganda:

$$
\begin{aligned}
& \mathrm{Y}=\mathrm{a}+\beta_{1} \mathrm{X}_{1}+\beta_{2} \mathrm{X}_{2}+\beta_{3} \mathrm{X}_{3}+\mathrm{e} \\
& \text { Tobin's } \mathrm{Q}=\mathrm{a}+\beta_{1} \mathrm{CSR}+\beta_{2} \mathrm{ROE}+ \\
& \quad+\mathrm{e} \\
& \text { Tobin's } \mathrm{Q}=-0,215+6,050 \mathrm{CSR}+ \\
& \text { 0,022ROE + 0,005DER + 0,33244 } \\
& \text { Keterangan: }
\end{aligned}
$$$$
\text { Tobin's } Q=a+\beta_{1} \text { CSR }+\beta_{2} \text { ROE }+\beta_{3} \text { DER }
$$

$\begin{array}{ll}\text { a } & =\text { Konstanta } \\ \text { Tobins Q } & =\text { Nilai Perusahaan } \\ \text { CSR } & =\text { Corporate Social } \\ & \quad \text { Responsibility } \\ \text { ROA } & =\text { Profitabilitas } \\ \text { DER } & =\text { Solvabilitas } \\ \mathrm{e} & =\text { standar eror }\end{array}$

Dapat dijelaskan hal-hal di bawah ini berdasarkan persamaan di atas:

1. Nilai Konstanta (a) $=-0,215$

Nilai konstanta diperoleh dengan nilai negatif sebesar -0,025. Artinya, jika CSR, Profitabilitas (ROE), dan Solvabilitas (DER) diasumsikan sama dengan nol atau konstan, sehingga akan turun menjadi $-0,215$ satuan atau $21,5 \%$ dalam nilai perusahaan (Tobin's Q).

2. Koefisien Regresi Variabel Corporate Social Responsibility $(\mathrm{CSR})=6,050$

Besarnya koefisien CSR sebesar 6,050 dengan nilai positif. Artinya, jika CSR naik sehingga akan naik di nilai perusahaan (Tobin's Q). Maksudnya jika variabel CSR (X1) bertambah 16,050 atau $60 \%$. Begitu pula jika jika CSR turun sehingga nilai perusahaan turun juga.

3. Koefisien Regresi Variabel Profitabilitas $(\mathrm{ROE})=0,022$

Koefisien ROE diperoleh sebesar 0,022. Berarti jika ROE meningkat maka Tobins' $Q$ juga meningkat. Maksudnya Tobins' $Q$ meningkat 0,022 atau 2,2\% jika ROE menambah 1 satuan. Sebaliknya jika ROE menurun maka Tobins'Q juga menurun. 
4. Koefisien Regresi Variabel Solvabilitas $(\mathrm{DER})=0,005$

Diperoleh koefisien DER 0,005 (positif). Jika DER meningkat maka Tobin's Q juga meningkat. Artinya Tobins'Q naik senilai 0,005 atau $0,5 \%$ jika DER naik 1 satuan. Sebaliknya jika DER menurun maka Tobins'Q juga menurun.

5. Standar Eror $=0,33244$

Berarti bahwa dengan standar eror memiliki 0,33244, maka variabel acak menyebar secara normal senilai $33,24 \%$ atau 0,33244 .

\section{Hasil Uji Hipotesis \\ Hasil Uji t (Uji parsial)}

Tabel 7

Hasil Uji t (Uji Parsial)

\begin{tabular}{|c|c|c|c|c|}
\hline \multicolumn{5}{|c|}{ Coefficients $^{\mathrm{a}}$} \\
\hline \multicolumn{2}{|c|}{ Model } & \multirow{2}{*}{$\frac{\mathbf{T}}{-.662}$} & \multirow{2}{*}{$\frac{\text { Sig. }}{.510}$} & \multirow[t]{2}{*}{ Keterangan } \\
\hline 1 & (Constant) & & & \\
\hline & CSR & 2.122 & .037 & $\begin{array}{l}\text { Berpengaruh } \\
\text { (H1 diterima) }\end{array}$ \\
\hline & $\begin{array}{l}\text { Profitabilitas } \\
\text { (ROE) }\end{array}$ & 4.460 & .000 & $\begin{array}{l}\text { Berpengaruh } \\
\text { (H2 diterima) }\end{array}$ \\
\hline & $\begin{array}{l}\text { Solvabilitas } \\
\text { (DER) }\end{array}$ & 6.135 & .000 & $\begin{array}{l}\text { Berpengaruh } \\
\text { (H3 diterima) }\end{array}$ \\
\hline
\end{tabular}

a. Dependent Variable: Nilai Perusahaan (Tobin's Q)

Sumber: Data penelitian diolah (2020) oleh SPSS v.16

Berdasarkan data penelitian yang digunakan diperoleh $\mathrm{t}$ tabel 1,99300 (berasal dari df residual sebesar n-k-1 (77$3-1=73)$ dan $\alpha / 2(0,05 / 2=0,025)$.

Hasil SPSS versi 16.0 diperoleh CSR menunjukkan $t$ hitung $>t$ tabel $(2,122>1,99300)$, signifikansi $0,037<0,05$. Sehingga hipotesis pertama diterima, yang artinya CSR mempengaruhi secara signifikan dan positif terhadap nilai perusahaan pada perusahaan properti dan perumahan yang listed di BEI periode 2012-2018.

ROE memperoleh $\mathrm{t}$ hitung $>\mathrm{t}$ tabel $(4,460>1,99300)$, signifikansi $0,000<0,05$. Maka hipotesis kedua diterima. Sehingga
ROE memiliki pengaruh positif dan signifikan terhadap nilai perusahaan pada perusahaan properti dan perumahan yang listed di BEI periode 2012-2018.

DER memiliki $t$ hitung $>\mathrm{t}$ tabel $(6,135>1,99300)$ dan signifikansi $0,000<0,05$. Jadi hipotesis ketiga diterima. Maka DER mempunyai pengaruh yang signifikan dan positif terhadap nilai perusahaan pada perusahaan properti dan perumahan yang listed di BEI periode 2012-2018.

Di bawah ini tabel dari variabel bebas yang paling mempengaruhi:

Tabel 8

Hasil Correlation Partial

\begin{tabular}{|c|c|c|c|c|}
\hline \multicolumn{5}{|c|}{ Coefficients $^{\mathbf{a}}$} \\
\hline & & \multicolumn{3}{|c|}{ Correlations } \\
\hline \multicolumn{2}{|c|}{ Model } & $\begin{array}{l}\text { Zero- } \\
\text { order }\end{array}$ & Partial & Part \\
\hline \multirow[t]{4}{*}{1} & (Constant) & & & \\
\hline & CSR & .407 & .241 & .182 \\
\hline & $\begin{array}{l}\text { Profitabilitas } \\
(\mathrm{ROE})\end{array}$ & .201 & .463 & .382 \\
\hline & $\begin{array}{l}\text { Solvabilitas } \\
\text { (DER) }\end{array}$ & .489 & .583 & .525 \\
\hline
\end{tabular}

a. Dependent Variable: Nilai Perusahaan (Tobin's Q)

Sumber: Data penelitian diolah (2020) oleh SPSS v.16

Berdasarkan hasil SPSS versi 16.0 di atas menunjukkan variabel bebas yang paling mempengaruhi yaitu solvabilitas (DER). Karena DER memiliki correlation partial 0,583. Sedangkan yang lainnya CSR memiliki 0,241 dan ROE memiliki 0,463 .

\section{Hasil Uji F (Model goodness of fit) Tabel 9 Hasil Uji F}

ANOVA ${ }^{b}$

\begin{tabular}{|c|c|c|c|c|c|c|}
\hline \multicolumn{2}{|c|}{ Model } & \begin{tabular}{|c|} 
Sum of \\
Square \\
s
\end{tabular} & Df & $\begin{array}{c}\text { Mean } \\
\text { Square }\end{array}$ & $\mathbf{F}$ & Sig. \\
\hline 1 & Regression & 7.036 & 3 & 2.345 & $\begin{array}{r}21.22 \\
1\end{array}$ & $.000^{\mathrm{a}}$ \\
\hline
\end{tabular}




\begin{tabular}{|l|l|r|r|r|l|l|}
\hline Residual & 8.068 & 73 & .111 & & \\
\hline Total & 15.104 & 76 & & & \\
\hline
\end{tabular}

a. Predictors: (Constant), Solvabilitas (DER), CSR, Profitabilitas (ROE)

b. Dependent Variable: Nilai Perusahaan (Tobin's Q)

Sumber: Data penelitian diolah (2020) oleh SPSS v.16

Dari data penelitian yang digunakan diperoleh $\mathrm{f}$ tabel $(2,73)$ berasal dari $\mathrm{df}_{1}\left(\mathrm{~N}_{1}\right)=\mathrm{k}-1=4-1=3, \mathrm{df}_{2}\left(\mathrm{~N}_{2}\right)=\mathrm{n}-\mathrm{k}$ $=77-4=73, \alpha$ (probabilitas) $=0,05$. Sehingga dari data tersebut diperoleh hasi SPSS versi 16.0 sebagai berikut: $f$ hitung $>\mathrm{f}$ tabel $(21,221>2,73)$ dan signifikansi $0,000<0,05$. Jadi hipotesis keempat diterima. Maksudnya CSR, solvabilitas (ROE), dan solvabilitas (DER) mempunyai pengaruh signifikan dan positif terhadap nilai perusahaan pada perusahaan properti dan perumahan yang listed di BEI periode 2012-2018.

\section{Hasil Uji $\mathbf{R}^{2}$ (Koefisien Determinasi) \\ Tabel 10 \\ Hasil Uji $R^{2}$ (Koefisien Determinasi)}

\begin{tabular}{|l|c|c|r|r|}
\multicolumn{9}{|c}{ Model Summary } \\
\begin{tabular}{|l|c|r|r|} 
Mod \\
el
\end{tabular} & $\mathbf{R}$ & $\begin{array}{c}\text { R } \\
\text { Squar } \\
\text { e }\end{array}$ & $\begin{array}{c}\text { Adjusted } \\
\text { R Square }\end{array}$ & $\begin{array}{c}\text { Std. Error } \\
\text { of the } \\
\text { Estimate }\end{array}$ \\
\hline 1 & .683 & .466 & .444 & .33244 \\
\hline
\end{tabular}

a. Predictors: (Constant), Solvabilitas (DER), CSR, Profitabilitas (ROE)

b. Dependent Variable: Nilai Perusahaan (Tobin's Q)

Sumber: Data penelitian diolah (2020) oleh SPSS v.16

Hasil SPSS versi 16.0 dari tabel di atas, bahwa CSR, profitabilitas (ROE), dan solvabilitas (DER) mampu mempengaruhi dan menjelaskan nilai perusahaan (Tobin's Q) sebesar 44,4\%. Karena adjusted $R$ Square diperoleh 0,444. Dengan variabel bebas yang menunjukkan hubungan cukup erat karena $R$ Square mendekati 1. 55,6\% nya dipengaruhi oleh variabel bebas lainnya.

\section{Pembahasan Hasil dan Interpretasi Hasil Penelitian}

\section{Pengaruh Corporate Social Responsibility terhadap Nilai Perusahaan}

Menurut hasil perhitungan melalui SPSS v.16.0 menunjukkan signifikansi $(0,037<0,05)$ dan $\mathrm{t}$ hitung $>\mathrm{t}$ tabel $(2,122>1,99300)$ serta memiliki nilai koefisien sebesar 6,050 dengan arah positif, sehingga $\mathrm{H} 1$ diterima. Berdasarkan hasil tersebut bahwa perusahaan properti dan perumahan yang telah mendisclousure informasi pertanggungjawaban sosial sebagai citra yang positif dan baik di shareholders dikalangan bisnis dan masyarakat karena entitas memperhatikan stakeholders dan lingkungannya, sehingga perusahaan akan mendapatkan respon yang posotif dari masyarakat, shareholders dan dikalangan bisnis untuk eksistensinya di dunia bisnis dan keberlanjutan perusahaan (going concern). Teori stakeholder mengatakan bahwa perusahaan harus memperhatikan kesejahteraan para pemegang saham, dengan diaplikasikannya CSR hal ini mampu untuk menarik simpati dari investor-investor untuk memberikan sahamnya.

Hasil tersebut diperoleh bahwa variabel CSR menggunakan rumus CSRIj $(\Sigma \mathrm{Xij}: \mathrm{Nj})$ sedangkan variabel nilai perusahaan (variabel dependen) menggunakan Tobin's Q $((\mathrm{EMV}+\mathrm{D})$ : $(\mathrm{EBV}+\mathrm{D}))$ sebagai rumusan. Dan didukung oleh (Syamsuddin \& Wardani, 2018), namun berbeda dengan hasil penelitian (Sriwidodo \& Sumaryanto, 2019).

\section{Pengaruh Profitabilitas terhadap Nilai Perusahaan}

Dari hasil penelitian melalui SPSS v.16.0, didapat bahwa $t$ hitung $>t$ tabel $(4,460>1,99300)$ dengan signifikansi $0,000<0,05$. Sehingga H2 diterima. Artinya ROE memiliki pengaruh yang positif dan 
signifikan terhadap nilai perusahaan (Tobin'Q) pada Perusahaan Properti dan Perumahan yang terdaftar di BEI periode 2012-2018 secara parsial.

Pada perusahaan Properti dan Perumahan profitabilitas (ROE) yang tinggi maka perusahaan memberi berita yang baik bagi penanam saham dan harga saham yang naik. Profitabilitas tinggi yang diproksikan dengan ROE meningkat maka mempengaruhi perubahan ekuitas yang meningkat, sehingga hrga saham akan meningkat.

Riset ini selaras oleh riset (Lumentut, F. G., \& Mangantar, 2019), (Komang Yulan Surmadewi \& Dewa Gede Dharma Saputra, 2019) dan penelitian (Awulle et al., 2018). Sedangkan tidak sejalan dengan penelitian yang dilakukan oleh (Itsnaini, H. M., \& Subardjo, 2017).

\section{Pengaruh Solvabilitas terhadap Nilai Perusahaan}

Hasil pengolahan SPSS v.16.0, didapat bahwa $\mathrm{t}$ htitung $>\mathrm{t}$ tabel $(6,135>1,99300)$ dan signifikansi $0,000<0,05$. Jadi H3 diterima. Artinya DER berpengaruh terhadap nilai perusahaan (Tobin'Q) pada Perusahaan Properti dan Perumahan yang listed di BEI periode 2012-2018 secara parsial.

Pada perusahaan Properti dan Perumahan solvabilitas meningkat sehingga memiliki kemampuan tinggi khususnya modal sendiri untuk dijadikan jaminan utang pada kreditor. Rasio DER yang tinggi menunjukkan perusahaan mampu memiliki seluruh ekuitas yang tinggi untuk jaminan pembayaran seluruh utang, baik utang yang memiliki periode lebih dari satu tahun atau kurang. Hal ini menaikkan nilai perusahaan karena semakin banyak investor yang menanamkan sahamnya dan harga saham mampu dikeluarkan perusahaan dengan nilai tinggi.

\section{Pengaruh Corporate Social Responsibility, Profitabilitas, dan Solvabilitas terhadap Nilai Perusahaan}

Dari uji SPSS versi. 16, didapat bahwa signifikansi menunjukkan $0,000>0,05$ dengan $f$ hitung $>f$ tabel $(21,221>2,73)$. Maka secara simultan variabel CSR, profitabilitas, dan solvabilitas mempunyai pengaruh signifikan dan positif terhadap nilai perusahaan pada Perusahaan Properti dan Perumahan listed di BEI periode 20122018. Sehingga H4 diterima.

Perusahaan Properti dan Perumahan CSR menunjukkan laba non financial bagi perusahaan karena menunjukkan kepeduliannya dan pertanggungjawabannya terhadap dampak yang dihasilkan bagi masyarakat dan lingkungan dalam bentuk kegiatan ekonomi, lingkungan, dan sosial. Profitabilitas menunjukkan kemampuan laba finansial yang mempengaruhi perubahan ekuitas yang diperoleh bagi perusahaan serta dapat meningkat dan mempengaruhi investor sehingga harga saham naik. Sedangkan solvabilitas akan menunjukkan kemampuan perusahaan dalam membayar dan memberikan jaminan terhadap utangnya baik jangka panjang maupun jangka pendek dengan tingginya seluruh ekuitas yang dimiliki.

Sehingga diharapkan harga saham pada nilai perusahaan kenaikannya mampu dipengaruhi oleh CSR, profitabilitas, dan solvabilitas yang tinggi. Riset ini searah dengan (Lumentut, F. G., \& Mangantar, 2019).

\section{KESIMPULAN \\ Kesimpulan}

Berdasarkan hasil analisis data dalam penelitian ini, adapun hasil kesimpulannya sebagai berikut:

1. Secara parsial CSR berpengaruh positif dan signifikan terhadap nilai perusahaan (Tobin's Q) pada Perusahaan Properti dan Perumahan yang Terdaftar di BEI tahun 2012-2018 dan tingkat signifikansi serta memiliki koefisien sebesar 6,050 dengan arah yang positif. Sehingga hipotesis pertama diterima. 
2. Secara parsial Profitabilitas (ROE) berpengaruh positif dan signifikan terhadap nilai perusahaan (Tobin's Q) pada Perusahaan Properti dan Perumahan yang Terdaftar di BEI tahun 2012-2018. Sehingga hipotesis kedua diterima.

3. Secara parsial Solvabilitas (DER) berpengaruh positif dan signifikan terhadap nilai perusahaan (Tobin's Q) pada Perusahaan Properti dan Perumahan yang Terdaftar di BEI tahun 2012-2018 dan tingkat signifikansi $0,000<0,05$. Sehingga hipotesis ketiga diterima.

4. Secara simultan CSR, Profitabilitas (ROE), dan Solvabilitas (DER) berpengaruh positif dan signifikan terhadap nilai perusahaan (Tobin's Q) pada Perusahaan Properti dan Perumahan yang Terdaftar di BEI tahun 2012-2018. Sehingga hipotesis keempat diterima.

\section{Keterbatasan}

Keterbatasan nya yaitu (1) kurangnya variabel independen lainnya. (2) proksi yang digunakan belum indikator secara keseluruhan dari variabel independennya begitu pula proksi variabel dependennya yang bisa dikembangkan. (3) penelitian ini hanya menggunakan faktor internal (CSR, profitabilitas, dan solvabilitas). (4) keterbatasannya yaitu periode yang digunakan dalam penelitian ini terbatas mulai 2012 sampei 2018, perlunya diupdate lagi untuk peneliti selanjutnya.

\section{Saran}

\section{Bagi Pemerintah dan Perusahaan}

Pemerintah harus lebih melihat secara detail laporan yang berhubungan dengan nilai perusahaan seperti CSR, profitabilitas, dan solvabilitas perusahaan khususnya yang sudah go public karena hal ini berhubungan dengan meningkatnya laba yang diperoleh perusahaan, bahwa laba perusahaan khususnya yang sudah go public mampu untuk meningkatkan pajak bagi negara untuk dimanfaatkan dalam kegiatan kemasyarakatan di negara khususnya Negara Indonesia.

Perusahaan utamanya pihak manajemen harusnya terus mempehatikan dan meningkatkan pengungkapan CSR, profitabilitas, dan solvabilitasnya sebab semua variabel bebas signifikan dan positif terhadap nilai perusahaan. Jadi pihak manajemen harus benar-benar jeli untuk mampu mempertahankan pengungkapan CSR, profitabilitas (ROE), dan solvabilitas (DER) bahkan terus meningkatkan.

2. Bagi Investor

Investor diharapkan lebih teliti dalam melihat informasi dan laporan mengenai perusahaan yang telah dipublikasikan dari tahun ke tahun khususnya mengenai hal-hal yang bisa berpengaruh terhadap nilai perusahaan sehingga dapat diperoleh perusahaan yang layak untuk ditempati investasi. Faktor-faktor tersebut yaitu CSR, profitabilitas, dan solvabilitas. Karena dalam penelitian saya CSR, profitabilitas (ROE), dan solvabilitas (DER) signifikan serta positif terhadap nilai perusahaan.

3. Bagi Dunia Akademik

mampu Dunia akademik diharapkan
mengembangkan hasil penelitian ini untuk digunakan acuan dan referesi dalam menyelesaikan tugas akhir. Supaya mampu mengembangkan teori baru yang mengungkapkan bahwa CSR, profitabilitas, dan solvabilitasnya signifikan dan positif terhadap nilai perusahaan khususnya Perusahaan Properti dan Perumahan listed di BEI periode 2012-2018 dan agar dikembangkan lagi teorinya untuk perusahaan lain seperti Perusahaan Perbankan listed di BEI periode 20202025 untuk mempertahankan hasil riset dan menemukan teori baru.

4. Bagi Peneliti Selanjutnya 
Supaya meneruskan untuk dikembangkan dengan variabel lainnya, Baik menambah atau mengganti. Seperti kebijakan utang, firm size, likuiditas, rentabilitas, ROA, DER dan PBV. Objek penelitian ditambah ataupun dirubah dengan objek lainnya seperti Perusahaan Perbankan listed di BEI periode 2020-2025.

\section{DAFTAR PUSTAKA}

Awulle, I. D., Murni, S., Rondonuwu, C. N., Sam, U., \& Manado, R. (2018). Pengaruh Profitabilitas Likuiditas Solvabilitas Dan Kepemilikan Institusional Terhadap Nilai Perusahaan Food and Beverage Yang Terdaftar Di Bursa Efek Indonesia Periode 2012-2016. Jurnal EMBA: Jurnal Riset Ekonomi, Manajemen, Bisnis Dan Akuntansi, 6(4), 19081917.

Dyah, S. (2019). MEA Tantangan Bagi Pengembang Lokal.

Fahmi, I. (2017). Analisis Laporan Keuangan. Alfabeta CV.

Hery. (2017). Kajian Riset AKuntansi. PT Grasindo.

Idx. (2019). No Title. https://idx.co.id/

Indonesia, C. (2019). Profitabilitas Lippo Karawaci Menurun.

Indonesia, I. A. (2018). PSAK No. 1 Revisi 2018. Ikatan Akuntan Indonesia.

Itsnaini, H. M., \& Subardjo, A. (2017). Pengaruh profitabilitas dan solvabilitas terhadap nilai perusahaan yang dimoderasi corporate social responsibility. Jurnal Ilmu Dan Riset Akuntansi, 6(6), 1-15.

Kasmir. (2016). Analisis Laporan Keuangan. PT Raja Grafindo Persada.

Komang Yulan Surmadewi, N., \& Dewa Gede Dharma Saputra, I. (2019). Pengaruh Likuiditas, Leverage, dan Profitabilitas Terhadap Nilai Perusahaan Pada Perusahaan Farmasi. E-Jurnal Ekonomi Dan Bisnis Universitas Udayana, 6, 567. https://doi.org/10.24843/eeb.2019.v08 .i06.p03
Lumentut, F. G., \& Mangantar, M. (2019). Pengaruh Likuiditas, Profitabilitas, Solvabilitas, Dan Aktivitas Terhadap Nilai Perusahaan Mannufaktur Yang Terdaftar Di Indeks Kompas100 Periode 2012-2016. Jurnal EMBA: Jurnal Riset Ekonomi, Manajemen, Bisnis Dan Akuntansi, 7(3), 26012610.

Sleekr. (2017). 4 Tanda Kondisi Keuangan Baik. https://sleekr.co/blog/4-tandakondisi-keuangan-baik/)

Solihin, I. (2015). Corporate Social Responsibility From Charity to Sustainability. Salemba Empat.

Sriwidodo, U., \& Sumaryanto. (2019). Analisis Return On Equity, Corporate Social Responsibility, Dan Good Corporate Governance Terhadap Nilai Perusahaan ( Survei Pada Perusahaan Manufaktur Di Bursa Efek Indonesia Tahun 2015-2016 ). Research Fair, Vol. 3(No. 1).

Syamsuddin, \& Wardani, B. K. (2018). Pengaruh Corporate Social Responsibility, Leverage dan Ukuran Perusahaan Terhadap Agresivitas Pajak (Studi Pada Perusahaan Sektor Pertambangan yang Terdaftar di Bursa Efek Indonesia tahun 2014 2016). The National Conference Management and Business (NCMAB) "Pemberdayaan Dan Penguatan Daya Saing Bisnis Dalam Era Digital," 5(2), 2139-2146. 